\title{
TOTAL PHENOLIC CONTENT AND FLAVONE BIOACTIVITY OF PEANUT HULLS AS ANTIOXIDANT AND ANTIPROLIFERATION TOWARD HENRIETTA LACKS CANCER CELLS
}

\author{
AIKA LATIFAH ALAWIYAH, SUMINAR S ACHMADI*, GUSTINI SYAHBIRIN \\ Department of Chemistry, Bogor Agricultural University, Bogor 16680, Indonesia. Email: ssachmadi@cbn.net.id
}

Received: 30 November 2016, Revised and Accepted: 04 January 2017

ABSTRACT

Objective: This study aimed to determine the total phenolic content, correlation of it with antioxidant capacity, and peanut hulls as an antiproliferation on Henrietta Lacks (HeLa) cancer cells, which Indonesia has a serious problem in term of cervix cancer

Methods: Peanut hulls were extracted by Soxhlet extraction, ultrasound vibration, and reflux boiling to obtain the best extraction method. The total phenolic content of the ethanol extract and the ethyl acetate fraction was determined using Folin-Ciocalteu method. The 2,2-diphenyl-1-picrylhydrazyl (DPPH) assay was used to evaluated an antioxidant capacity of both samples. Identification of the isolated flavone was done by ultraviolet spectra and analyzed using liquid chromatography-mass spectrometer. Inhibition of proliferation of HeLa cancer cells was tested for the purified fraction using 3-(4,5-dimethyl thiazole-2-yl)-2, 5-diphenyltetrazolium bromide assay.

Results: The results of total phenolic content determination giving 262 (ethanol extract) and 532 (ethyl acetate fraction) mg gallic acid equivalent/g extract, respectively. DPPH assay resulted antioxidant capacity with value of inhibitory concentration $50 \%$ (IC ${ }_{50}$ ) was 36.36 (ethanol extract) and 18.68 (ethyl acetate fraction) $\mu \mathrm{g} / \mathrm{mL}$, respectively. Identification of isolated flavone resulted an apigenin and indicated moderate potency in inhibiting the proliferation of HeLa cancer cells with $\mathrm{IC}_{50}$ value of $34 \mu \mathrm{g} / \mathrm{mL}$.

Conclusions: There was a correlation between the total phenolics with antioxidant capacity of the peanut hulls. The isolated flavone is predominated by apigenin. This isolated compound is potential as antioxidant and inhibiting the proliferation of HeLa cancer cells moderately.

Keywords: Peanut hulls, Total phenolic, Antioxidant capacity, Flavone, Apigenin, Henrietta Lacks cancer cells.

(C) 2017 The Authors. Published by Innovare Academic Sciences Pvt Ltd. This is an open access article under the CC BY license (http://creativecommons. org/licenses/by/4. 0/) DOI: http://dx.doi.org/10.22159/ajpcr.2017.v10i4.16399

\section{INTRODUCTION}

Peanut plants are the largest crop production in Indonesia after soybeans. The seeds and the skin have been studied to have benefits in medicinal chemistry, such as for antioxidant and anticancer [1]. On the other hand, the peanut hulls contain eriodictyol, polyphenols, 5,7-dihydroxychromone, and luteolin [2-4]. Previous studied were reported that the phenolic compounds have pharmacological activity, such as antibacterial, anti-inflammatory, and larvacidal activities, as well as an antioxidant activity [5-7].

Antioxidant capacity correlates with the concentration of substances in a material [8]. The high of total phenolic content showed high antioxidant activity and can inhibit cancer cell growth effectively [9]. Cervical cancer is a serious problem for women. This cancer is the second biggest killer after breast cancers occur in women. In 2012, women who developed cervical cancer reached $84 \%$ of new cases occurred worldwide [10]. Flavones are one of the phenolic compounds that have been identified as an antioxidant and anticancer potential. Gao et al. [11] identified the presence of apigenin in the ethyl acetate fraction of Cajanus cajan and it exhibits activities as a strong antioxidant. Apigenin, as an antioxidant, has been proven in inhibiting the growth of cancer cells, such as lung (MRC-5), breast (MCF7), colon (HT-29), and cervical (Henrietta Lacks [HeLa]) cancer cell. Proliferation inhibition of this flavone was the highest against MCF7 and HeLa among cancer cells [12]. A chemical constituent in a material needs to be determined for the evaluation as an antioxidant and inhibitory activity against cancer cells. Therefore, this study aims to determine the total phenolic content, antioxidant activity, and antiproliferation of flavones isolated from peanut hulls toward HeLa cancer cells in vitro.

\section{METHODS}

Plant material

The peanut hulls were collected from Sukabumi area was verified as leguminous Arachis hypogaea L. by the Bogoriense Herbarium,
Department of Botany Research Center for Biology LIPI, Bogor, Indonesia. The sample was cleaned and dried at room temperature, pulverized, and determined for the moisture content.

\section{Chemicals and instrumentation}

Gallic acid, Folin-Ciocalteu reagents, 2,2-diphenyl-1-picrylhydrazyl (DPPH), and ascorbic acid were purchased from a chemical vendor. Three different extraction apparatus were employed: Ultrasonic vibrator, reflux unit, and Soxhlet extractor. Vero cells (ATCC CCL 81), HeLa cancer cells (ATCC CCL 2), Dulbecco's Modified Eagle Medium (DMEM) (Gibco), 3-(4,5-dimethylthiazole-2-yl)-2, 5-diphenyltetrazolium bromide (MTT) (Sigma), dimethyl sulfoxide (DMSO), and doxorubicin were provided by the Primate Center of Bogor Agricultural University. Ultraviolet-visible (UV-Vis) spectrophotometer (HITACHI UV/Vis Spectrophotometer U2800) and liquid chromatography-mass spectrometer (LC-MS) (Waters Acquity) were used for chemical structure identification that done in the Laboratorium Kesehatan Daerah Jakarta, Indonesia.

\section{Phytochemical assays for phenolic and flavonoids}

The assays for phenolic and flavonoids content in the powder form and in the extract of peanut hulls were based on Harborne method [13]. The existence of phenolic was characterized by purple, dark blue, and black or greenish color in the solution, whereas the presence of flavonoids was shown in red/yellow/orange on layers of amyl alcohol.

Preparation of ethanol extract

Dried powder (20 g) was extracted with ethanol 96\% using three extraction methods (Soxhlet extraction, ultrasound vibration, and reflux boiling) to obtain the best extraction method $[2,6,14]$. Furthermore, the powder (900 g) was extracted using the best extraction method, which was boiling under reflux, for 210 minutes, then filtered. The filtrate was evaporated using a vacuum rotary evaporator (BUCHI Rotavapor R-114). 
The ethanol extract was further treated with liquid-liquid extraction using $\mathrm{n}$-hexane, giving $\mathrm{n}$-hexane and ethanol fractions. The ethanol fraction was hydrolyzed using $\mathrm{HCl} 2 \mathrm{~N}$. The acid hydrolyzate was fractionated using ethyl acetate. The ethyl acetate fraction was impregnated into silica gel until all of the material absorbed in the silica in a column chromatograph. The elution was started with $n$-hexane, followed by a gradient mixture of n-hexane: Dichloromethane (DCM), DCM, DCM: Methanol, and finally with methanol [15]. This process gave fractions that were collected and identified of isolated flavone based on thin layer chromatography (TLC), UV-Vis spectrophotometry, and LC-MS.

\section{Determination of total phenolic content}

The crude ethanol extracts from the Soxhlet, ultrasound, and reflux extractions were subjected to total phenolic determination. Each of the extract was dissolved in methanol, added with Folin-Ciocalteu reagent and incubated for 8 minutes at $25^{\circ} \mathrm{C}$. Subsequently, $\mathrm{NaOH} 1 \%$ solution was added and the incubation was continued for another hour. The absorbance was measured at a wavelength of $730 \mathrm{~nm}$ using a UV-Vis spectrophotometer. The gallic acid solution with a concentration series was used as standards. This total phenolic assay was employed for ethyl acetate fraction as well.

\section{Antioxidant activity by DPPH radical scavenging assay}

The crude extract and ethyl acetate fraction solution were prepared at various concentrations $(10-150 \mathrm{mg} / \mathrm{mL})$, and ascorbic acid was used as a positive control. To each of solution, $10 \mathrm{~mL}$ of reagent DPPH was added. The blank solution was prepared by dissolving DPPH in ethanol without any additional test solution. The mixture was shaken, incubated for 30 minutes at room temperature, and the absorbance was read at a wavelength of $517 \mathrm{~nm}$. The absorbance of DPPH was measured to obtain a percentage of DPPH radical scavenging. Antioxidant capacity of the sample was determined as the inhibitory concentration $50 \%\left(\mathrm{IC}_{50}\right)$ value. Antioxidant capacity of the isolated flavone was carried out similarly.

\section{Antiproliferation activity against HeLa cells using MTT assay}

The crude ethanol extract, ethyl acetate fraction, and flavones isolated from peanut hulls were tested first to Vero (normal) cells to determine the concentrations that are required in cancer cells assay. Safe concentrations on testing against Vero cells were then selected to be tested on HeLa cancer cells. Both types of cells were cultured in a prepared medium. The medium of DMEM was added with Fetal Bovine Serum (FBS) 10\% and penicillin-streptomycin $1 \%$. The cell suspension in the medium was placed into 96 -well microtiter plastic plates, and then incubated at $37^{\circ} \mathrm{C}$ for 24 hrs under $5 \% \mathrm{CO}_{2}$ atmosphere. The crude extract, ethyl acetate fraction, and the isolated flavone were each dissolved in DMSO in different concentrations that had been determined previously, and then added to the cell suspension on the plate. Subsequently, the plate was incubated at $37^{\circ} \mathrm{C}$ under $5 \% \mathrm{CO}_{2}$ atmosphere for $48 \mathrm{hrs}$. DMEM medium without test solution and Doxorubicin ${ }^{\circledR}$ were prepared as a negative and positive controls. In the following step, the medium in the plate was aspirated and MTT reagent was added. The samples in the plate were incubated for $4 \mathrm{hrs}$ to form purple formazan in the living cells. Sodium Dedocyl Sulfate (SDS) solution $(1 \%)$ was added to each well and further incubated for $24 \mathrm{hrs}$ at room temperature. The absorbance was measured using an enzymelinked immunosorbent assay reader spectrophotometer at a wavelength of $595 \mathrm{~nm}$. The $\mathrm{IC}_{50}$ value was determined using the linear regression equation that states the relationship between the concentrations of the test sample and the inhibition, reported in percentage.

\section{Statistical analysis}

Correlation between total phenolic and antioxidant capacity was determined using Pearson procedure $(\mathrm{p}<0.01)$ through the application of SPSS version 23.

\section{RESULTS AND DISCUSSION}

Phenolics and flavonoids

The result of the phytochemical qualitative test showed that the dried powder and the ethanol extract of peanut hulls contained both phenolics and flavonoids (Table 1). The presence of phenolics was showed by yellow to green-black color, while the presence of flavonoids was highlighted in yellow in the amyl alcohol layer. Velu et al. [6] also reported that methanol, acetone, and aqueous extracts of peanut hull have a high content of phenolics and flavonoids based on phytochemical screening.

\section{Flavone extract}

The three different extraction methods gave different yields, being the boiling under reflux gave the highest in terms of crude extract (Table 2). The temperature and time of extraction at reflux boiling turns out to be the most effective in extracting flavonoids from the peanut hulls powder. Soxhlet extraction also uses boiling temperature, but only gives half of that obtained by refluxing, due to a minimum of contact between solvent and the sample. Ultrasound vibration is less efficient in extracting flavones from the peanut hull powder matrix. Although this extraction method uses ultrasonic waves, which helps in breaking the plant cell membrane, it needs longer time and higher temperature to obtain a higher yield of extracts. Extraction temperature below $80^{\circ} \mathrm{C}$ may also minimize the degradation of flavonoids [16].

Flavonoids were obtained from the ethanol extract by fractionation using ethyl acetate. First, the extract from the reflux boiling method was fractionated using n-hexane, giving n-hexane and ethanol fractions were hydrolyzed using $\mathrm{HCl} 2 \mathrm{~N}$ to break the glycoside bond. This study used $\mathrm{HCl}$ for hydrolysis because it is a strong catalyst that capable for breaking the glycosidic bond of a sugar group attached to the flavonoid [17]. The hydrolyzate was purified using ethyl acetate to collect the corresponding aglycone of the flavonoids. The yield of ethyl acetate fraction was slightly higher than that of the ethanol extract, i.e., $44.9 \%$ and $40.7 \%$, respectively. The result indicated that the flavonoid aglycone is effectively extracted in ethyl acetate solvent.

\section{The isolated flavone}

The hydrolyzed ethyl acetate fraction was further purified to obtain flavones using column chromatography. The best eluent for this purpose was a mixture of DCM: Methanol (29:2 v/v). The fractions were collected in 589 vials and gave 14 subfractions. The highest yield $(24.9 \%)$ was detected in subfraction L. On TLC plate, this particular subfraction showed phosphorescence blue $(\mathrm{Rf}=0.33$ ) and yellow ( $R f=0.23$ ), observed under UV light at wavelengths of 254 and $366 \mathrm{~nm}$, respectively. Again, the results on TLC using Forestal ( $\left.\mathrm{HCl}: \mathrm{HOAc:} \mathrm{H}_{2} \mathrm{O}\right)$ eluent in 3:30:10 v/v ratio and butanol:acetic acid:water $(4: 1: 5 \mathrm{v} / \mathrm{v})$, the isolated flavone exhibited Rf values of 0.81 and 0.90 , respectively. These Rfs indicated the presence of apigenin.

Absorption peaks appeared at 342,297.5, and $220 \mathrm{~nm}$ wavelengths on the UV-Vis spectra. Absorption at $200-400 \mathrm{~nm}$ indicated the presence of chromophore group, which is one of the characteristics of flavones. The isolated material was assumed to contain flavonoids, as previously

Table 1: Phenolics and flavonoids in the peanut hulls

\begin{tabular}{lll}
\hline Compound & Peanut hulls & \\
\cline { 2 - 3 } & Dried powder & Ethanol extract \\
\hline Phenolics & ++ & +++ \\
Flavonoids & + & ++ \\
\hline
\end{tabular}

Table 2: The crude extract yield of three extraction methods (from $20 \mathrm{~g}$ dry mass of sample)

\begin{tabular}{llll}
\hline $\begin{array}{l}\text { Extraction } \\
\text { method }\end{array}$ & $\begin{array}{l}\text { Time of extraction } \\
\text { (minutes) }\end{array}$ & $\begin{array}{l}\text { Extract } \\
\text { mass (g) }\end{array}$ & Yield (\%) \\
\hline Reflux boiling & 210 & $3.35 \pm 0.14$ & 18.76 \\
$\begin{array}{l}\text { Soxhlet extraction } \\
\text { Ultrasound }\end{array}$ & 540 & $1.65 \pm 0.33$ & 9.24 \\
vibration & 120 & $1.33 \pm 0.49$ & 7.45 \\
\hline
\end{tabular}


reported, namely by the appearance of the first peak at $310-350 \mathrm{~nm}$ and $297.5 \mathrm{~nm}$ of the second peak [18].

Analysis using LC-MS exhibited two peaks of high intensity at retention times of 1.93 and 10.8 minutes, being the highest peak at retention time of 10.8 minutes. Fragmentation of the molecular ion peak was found at $\mathrm{m} / \mathrm{z} 271$, and more fragments at $\mathrm{m} / \mathrm{z} 153,145,119,121$, and 243 . Once again, the fragmentation is similar to that of apigenin aglycone. The previous report suggested that the structure of the ion at $\mathrm{m} / \mathrm{z} 271$ is an aglycone of apigenin with fragmentation patterns of MS/MS 247, 229, $225,171,153,145$, and 119 [19]. However, there was another peak with low intensity at $\mathrm{m} / \mathrm{z} 271$, contributed by some impurities. Therefore, the isolated flavone was confirmed to be flavonoids, dominated by apigenin (Fig. 1).

\section{Total phenolic content}

Total phenolic content correlates with the bioactivity. In the assay, the reaction that occurred is marked by the formation of a blue color in solution after the addition of a base that can be measured an absorbance at $730 \mathrm{~nm}$. The hydroxyl group of phenolic would reduce heteropoly acids (phosphomolybdate-phosphotungstate) contained in the FolinCiocalteu reagent into a complex of molybdenum-tungsten blue. The total phenolic content was determined on the three crude extracts (Table 3). The reflux boiling is more effective to extract phenolic and flavonoids; the heat treatment may liberate and activate the low molecular weight of polymeric molecule subunit [20].The total phenolic content of the crude extract was $262.3 \mathrm{mg}$ gallic acid equivalent (GAE)/g extract. This value is much higher than that reported by others, using the same sample and the same reflux boiling, which is only $69.1 \mathrm{mg}$ GAE/g. By ultrasound vibration and domestic microwave maceration they only get 5.94 and $7.79 \mathrm{mg} \mathrm{GAE} / \mathrm{g}$ extract, respectively [14,21].

The total phenolic content in the ethyl acetate fraction was twice higher than that in ethanol extract (Table 4). This is understood due to the higher content of aglycone resulting from the hydrolysis, as the sugar moieties were removed. The total phenolics in this study is also higher that reported elsewhere, may be due to differences in the growth regions of peanut plants, as affected by temperature, soil, rainfall, humidity, and light intensity required by the plants [22]. These factors cause the chemical constituents of the plant to be diverse [23].

\section{Antioxidant activity}

The three samples from various extraction stages had different antioxidant activity in DPPH free radicals scavenging at the concentrations $<80 \mu \mathrm{g} / \mathrm{mL}$, until they reached approximately $95 \%$ scavenging activity (Table 5). On the other hand, pure ascorbic acid as a positive control gives the same activity at only $<20 \mu \mathrm{g} / \mathrm{mL}$. Based on this preliminary data, the values of $\mathrm{IC}_{50}$ were calculated. Antioxidant capacity of the ethyl acetate fraction is higher than that of the ethanol extract (Table 6).

The purified extract has caused the higher content of bioactive compounds than that of the crude extract where most components that interfere with activities such as fats and waxes are eliminated [24]. Flavonoids such as flavones, flavanols, and flavonols more attracted by the ethyl acetate solvent due to its low polarity. These compounds have hydroxyl groups which are able to supply hydrogen to be responsible in DPPH radical scavenging $[25,26]$. Many studies have found that phenolic functional group showed high antioxidant activity as explained by the ability to scavenge radicals. The released hydrogen atom of the hydroxyl group is bound by radicals and attains stable radical fenocyl [27].

Antioxidant activity of peel and skin of peanuts has been studied using different methods, i.e., DPPH radical scavenging, the ferrous ion chelating, reducing power, and ABTS ${ }^{*+}$ assay. According to the DPPH assay, acetone extract from the samples had antioxidant activity with a strong category on $\mathrm{IC}_{50}$ values of $50 \leq \mathrm{IC}_{50} \leq 100$ (or between 70.51 and $52.18 \mu \mathrm{g} / \mathrm{mL}$ ) [1]. The effect of acid hydrolysis in the extract which resulted aglycone form in ethyl acetate fraction was also clearly explained. Antioxidant capacity of the aglycone is higher than the glycoside as sugar can interfere with the radicals scavenging, so reducing the efficiency of its activity [17]. Meanwhile, the antioxidant capacity of the isolated flavone was similar with the ethyl acetate fraction that had $\mathrm{IC}_{50}$ value of $19.66 \mathrm{mg} / \mathrm{mL}$.

The $\mathrm{IC}_{50}$ values were based on linear regression equation of samples, which were $\left(y=0.7819 x+21.566, R^{2}=0.9405 ; y=2.385 x+5.540\right.$, $\mathrm{R}^{2}=0.972$; and $\left.\mathrm{y}=2.4439 \mathrm{x}+5.1178, \mathrm{R}^{2}=0.9918\right)$. There was a correlation between the level of total phenolic and antioxidant capacity (Table 7). This statement is based on an analysis using Pearson correlation $(\mathrm{p}<0.01, \mathrm{r}=-1)$. There was a correlation between total phenolic content and antioxidant activity. The higher total phenolic content gave the higher the antioxidant activity. A strong and significant correlation indicated that phenolic compounds in the peanut hulls play an important role as a strong antioxidant and should be able to inhibit the growth of cancer cells.

Table 3: Total phenolic content of extract resulted from 3 extraction methods

\begin{tabular}{lll}
\hline Extraction method & $\begin{array}{l}\text { Total phenolics } \\
\text { (mg GAE/g extract) }\end{array}$ & Total phenolics (\%) \\
\hline Reflux boiling & 496.84 & 49.7 \\
Soxhlet & 65.30 & 6.5 \\
Ultrasound vibration & 37.32 & 3.7 \\
\hline
\end{tabular}

GAE: Gallic acid equivalent

Table 4: Total phenolic content of ethanol extract and ethyl acetate fraction

\begin{tabular}{ll}
\hline Sample & Total phenolics (mg GAE/g wet sample) \\
\hline Ethanol extract & 262.30 \\
Ethyl acetate fraction & 531.90 \\
\hline
\end{tabular}

GAE: Gallic acid equivalent

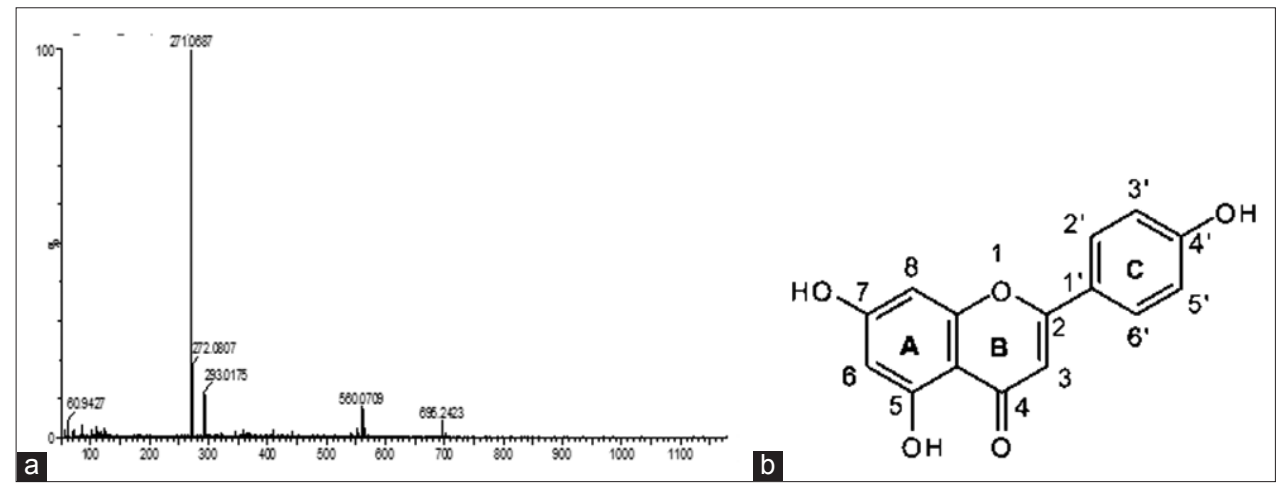

Fig. 1: Mass spectrum of the isolated flavone containing apigenin (a) and structure of apigenin (b) 
Table 5: Percentage of DPPH radical scavenging activity (\%)

\begin{tabular}{|c|c|c|c|c|c|}
\hline \multirow{2}{*}{$\begin{array}{l}\text { Concentration of } \\
\text { sample }(\mu \mathrm{g} / \mathrm{mL})\end{array}$} & \multicolumn{3}{|l|}{ Sample (\%) } & \multirow{2}{*}{$\begin{array}{l}\text { Concentration of ascorbic } \\
\text { acid }(\mu \mathrm{g} / \mathrm{mL})\end{array}$} & \multirow[t]{2}{*}{ Ascorbic acid (\%) } \\
\hline & Ethanol extract & Ethyl acetate fraction & Isolated flavone & & \\
\hline 140 & $92.5 \pm 0.17$ & 96.5 & $93.0 \pm 0.12$ & 20 & $95.8 \pm 0.25$ \\
\hline 100 & $91.7 \pm 0.85$ & $95.8 \pm 0.12$ & $92.6 \pm 0.25$ & 5 & $54.3 \pm 1.52$ \\
\hline 80 & $88.7 \pm 1.10$ & $95.3 \pm 0.12$ & $92.7 \pm 0.12$ & 2.5 & $27.0 \pm 1.52$ \\
\hline 60 & $75.7 \pm 1.61$ & $93.5 \pm 1.12$ & $92.1 \pm 0.12$ & 1.25 & $13.8 \pm 1.27$ \\
\hline 40 & $55.5 \pm 1.70$ & $93.1 \pm 1.50$ & $91.1 \pm 0.12$ & 0.62 & $8.1 \pm 0.76$ \\
\hline 20 & $31.9 \pm 0.34$ & $77.8 \pm 2.87$ & $86.7 \pm 2.00$ & 0.31 & $4.3 \pm 0.50$ \\
\hline
\end{tabular}

DPPH: 2,2-diphenyl-1-picrylhydrazyl

Table 6: Antioxidant capacity of samples

\begin{tabular}{ll}
\hline Sample & IC $_{50}(\mu \mathrm{g} / \mathrm{mL})$ \\
\hline Ethanol extract & 36.36 \\
Ethyl acetate fraction & 18.68 \\
Isolated flavone & 19.66 \\
\hline
\end{tabular}

$\mathrm{IC}_{50}$ : Inhibitory concentration $50 \%$

Table 7: Pearson correlation between total phenolic content and antioxidant capacity

\begin{tabular}{ll}
\hline Antioxidant capacity of samples & Total phenolic content \\
\hline Ethanol extract & $-1.000^{* *}$ \\
Ethyl acetate fraction & $-1.000^{* *}$ \\
\hline
\end{tabular}

${ }^{* *}$ Correlation is significant at the 0.01 level

\section{Antiproliferation activity on HeLa cancer cells}

Flavonoids role as an impediment to the growth of cervix (HeLa) [28], breast (MCF7), colon (HT-29), and lung (MRC-5) cancer cells [12]. Any sample can be regarded as inhibiting the antiproliferation of cancer cells if it has properties of high toxicity to the cells. However, cytotoxicity to cancer cell from the tested sample must consider the effects on normal (Vero) cells in the body. The toxicity assay on Vero cells at the ethanol extract, the ethyl acetate fraction, and the isolated flavone showed different inhibitory actions. The sample was toxic to Vero cells at concentrations $>150 \mu \mathrm{g} / \mathrm{mL}$, as represented by percent mortality of $50.6 \%, 49.9 \%$, and $64.2 \%$ with $\mathrm{IC}_{50}$ value of 254,161 , and $153 \mu \mathrm{g} / \mathrm{mL}$, respectively. The concentration of sample up $150 \mu \mathrm{g} / \mathrm{mL}$ has been able to kill Vero cells resulting in damage to the membrane so that the Trypan blue binds to proteins in the cell that indicate dead cells that turn to blue under microscopic observation [29]. Therefore, concentrations of $<150 \mu \mathrm{g} / \mathrm{mL}$ are safely used for Vero cells but should have the cytotoxic effect on HeLa cancer cells.

The ethanol extract, ethyl acetate fraction, and the isolated flavone were tested on HeLa cancer cells with different safe concentrations for Vero cells. Among the three samples, the isolated flavone exhibited the highest cytotoxicity as compared to the crude extract and the ethyl acetate fraction (Table 8). Flavonoids in the isolated flavone presumably serve as good antiproliferation agents for HeLa cancer cells. The inhibition percentage of this material toward HeLa cells reached 83\% at $150 \mu \mathrm{g} / \mathrm{mL}$. It is similar to giving Doxorubicin ${ }^{\circledR}$ at a concentration of $0.5 \mu \mathrm{g} / \mathrm{mL}$. Doxorubicin was used as a positive control because it has a strong cytotoxic against HeLa cells.

According to Table 9, the isolated flavone demonstrates the highest toxicity as compared with the ethanol extract and the ethyl acetate fraction. It also has inhibition against cancer cells with a moderate category.

It can be said that all the three test samples from the peanut hulls had potential as an antioxidant and inhibited the proliferation of cancer cells as reported by Pushpa et al. [30], metanol extract of Ganoderma applanatum basidiocarp and G. applanatum mycelium had potential as an antioxidant to antitumor, which important for the development new therapeutic agents. Proliferation inhibition of the both was higher on HeLa cancer cells by $\mathrm{IC}_{50}$ value found to be $10 \pm 0.07$ and $9.25 \pm 0.05 \mu \mathrm{g} / \mathrm{mL}$ than human liver (Hep G2) and human mammary gland; epithelial; ascites; ductal carcinoma (ZR-75-30) cancer cells.

Fig. 2 revealed the differences in proliferation inhibition of the samples in microscopic observation on the HeLa cancer cells. A plant extract predominated by flavonoids has been tested for cytotoxicity toward some cancer cells in vitro, namely HeLa cells, MCF7, HT-29, and MRC-5. The results proved that the extract was very toxic to HeLa and MCF7 cells at doses of 444 and $179 \mu \mathrm{g} / \mathrm{mL}$, respectively [9]. The inhibition percentage of doxorubicin in HeLa cells can reach $83 \%$ after $72 \mathrm{hrs}$ of incubation at certain doses [31]. In another study [32], methanol extract and ethyl acetate fraction of Convolvulus arvensis seeds showed high cytotoxicity against the same cancer cells with the $\mathrm{IC}_{50}$ values of $17.33 \pm 0.58$ and $28.52 \pm 1.28 \mu \mathrm{g} / \mathrm{mL}$, respectively. Those studies support the role of phenolics and flavonoids in the methanol extract and ethyl acetate fraction.

The isolated flavone was dominated by the presence of compound that has been identified as apigenin based on LC-MS analysis. The effectiveness of a material to inhibit the growth of cancer cells depend on the concentration, and types of cancer cell. Apigenin in our isolated flavone inhibits proliferation of HeLa cells strongly as well as demonstrated by chrysin and luteolin [33]. The structure of the apigenin which has double bonds $\mathrm{C} 2-\mathrm{C} 3$ relates to its cytotoxicity. Flavonoids (such as apigenin, luteolin, and quercetin) have higher toxicity than that of flavanones (such as taxifolin, naringenin, and eriodictiol) that only have a single bond at the C2-C3 based on the difference in effective concentration $50 \%$ values. The presence of other functional groups such as carbonyl groups at $\mathrm{C} 4$ affects the cytotoxicity level. Flavonoids that have a carbonyl group at the $\mathrm{C} 4$ has a higher cytotoxic effect on incubation time to 24 and $48 \mathrm{hrs}$ as compared with the compound without. Apigenin does not have a hydroxyl group at C3 as well as luteolin and eriodictiol, but this gives the effect of increasing the cytotoxicity of compounds for up to 2-10 times compared to with the compound having a hydroxyl group at C3 [34]. Apigenin has strong potential in preventing the growth of cervical cancer cells (HeLa) with $\mathrm{IC}_{50}$ values of $36 \mu \mathrm{M}$. This proliferation inhibition process can be through various pathways including apoptosis cell through the process arrested the cell cycle that causes the growth of cancer cells, modulating the p53 pathway, and the arrangements made by Bcl-2. The inhibition pathways lead to this HeLa cell apoptosis. P53 tumor suppressor gene is regarded as a major factor in maintaining a balance between growth and death cell as well as providing an important role in inhibiting growth tumor by inducing apoptosis [35].

\section{CONCLUSION}

Based on Pearson correlation analysis $(\mathrm{p}<0.01, \mathrm{r}=-1)$, there is a correlation between the total phenolics with antioxidant capacity of the peanut hulls. The total phenolics in the ethyl acetate fraction is higher than that of the ethanol extract so that the antioxidant capacity is higher 


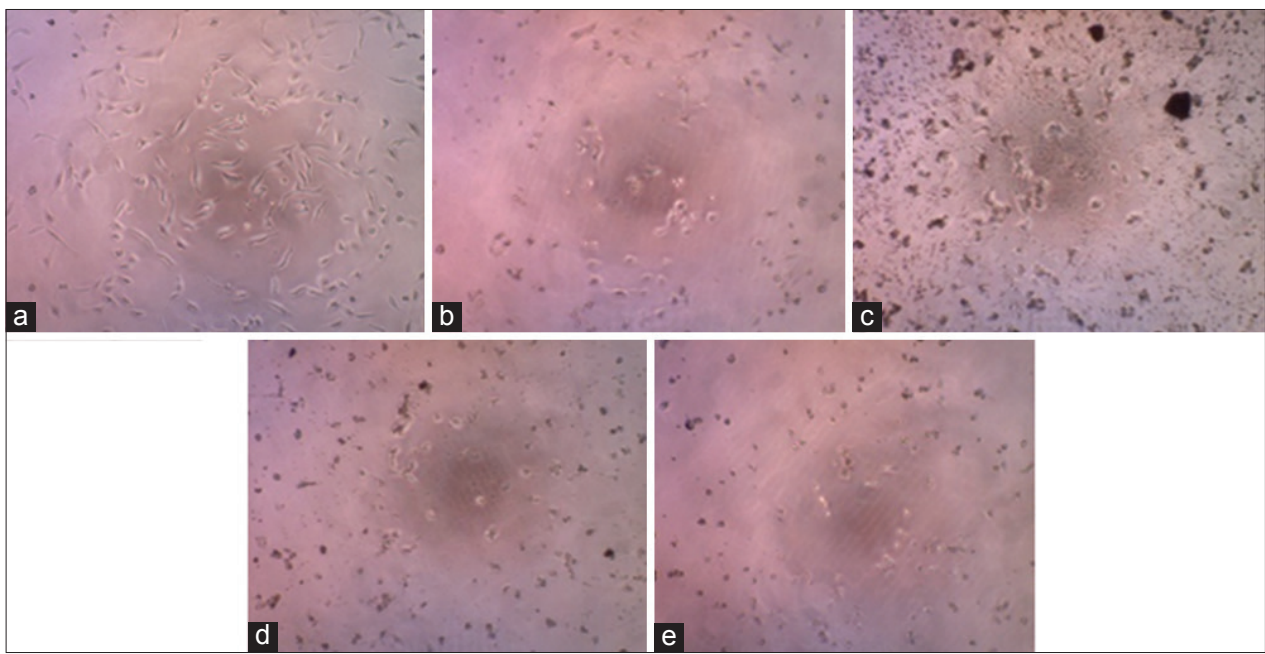

Fig. 2: Untreated Henrietta Lacks (HeLa) cancer cells (a); Proliferation inhibition by ethanol extract (b); by ethyl acetate fraction (c), by the isolated flavone (d), and by doxorubicin as positive control (e) on HeLa cancer cells

Table 8: Inhibition of sample on HeLa cancer cell proliferation

\begin{tabular}{|c|c|c|c|c|c|}
\hline \multirow[t]{2}{*}{ Concentration $(\mu \mathrm{g} / \mathrm{mL})$} & \multicolumn{3}{|l|}{ Sample (\%) } & \multirow[t]{2}{*}{ Concentration $(\mu \mathrm{g} / \mathrm{mL})$} & \multirow[t]{2}{*}{ Doxorubicin (\%) } \\
\hline & Ethanol extract & Ethyl acetate fraction & Isolated flavone & & \\
\hline 150 & $64.2 \pm 4.89$ & $62.8 \pm 10.13$ & $83.6 \pm 0.90$ & 1 & $93.0 \pm 1.04$ \\
\hline 37.5 & $31.8 \pm 2.65$ & $34.4 \pm 1.17$ & $48.6 \pm 3.35$ & 0.25 & $50.3 \pm 2.37$ \\
\hline 18.75 & $22.0 \pm 0.85$ & $32.2 \pm 2.50$ & $19.9 \pm 5.55$ & 0.125 & $54.0 \pm 2.17$ \\
\hline 9.38 & $14.2 \pm 4.84$ & $28.6 \pm 1.76$ & $14.9 \pm 2.24$ & 0.06 & $40.9 \pm 3.99$ \\
\hline 4.69 & $16.4 \pm 5.14$ & $29.5 \pm 2.43$ & $18.2 \pm 5.28$ & 0.03 & $42.6 \pm 1.30$ \\
\hline
\end{tabular}

HeLa: Henrietta Lacks

Table 9: Cytotoxic effect of sample on HeLa cancer cell based on IC $_{50}$ value

\begin{tabular}{ll}
\hline Samples & $\mathbf{I C}_{\mathbf{5 0}}(\boldsymbol{\mu g} / \mathbf{m L})$ \\
\hline Ethanol extract & 79.50 \\
Ethyl acetate fraction & 73.74 \\
Isolated flavone & 34.11 \\
\hline
\end{tabular}

$\mathrm{IC}_{50}$ : Inhibitory concentration $50 \%$

correspondingly with $\mathrm{IC}_{50}$ value approximately $20 \mu \mathrm{g} / \mathrm{mL}$ as compared with ethanol extract. The isolated flavone is predominated by apigenin. This isolated compound is potential as antioxidant and inhibiting the proliferation of HeLa cancer cells moderately with IC ${ }_{50} 34 \mu \mathrm{g} / \mathrm{mL}$. Based on this study it is evident that peanut hulls should not be wasted but to be used as an herbal medicine instead. It is also important to test the isolated flavone toward other cancer cells before these materials can serve as a cancer drug.

\section{REFERENCES}

1. Gaafar AA, Mahmoud KM, Salama ZA. Antioxidant potential activity and cytotoxicity effects of different parts of peanuts (Arachis hypogea L.). Int J Pharm Bio Sci 2015;6(3):19-32.

2. Qiu J, Chen L, Zhu Q, Wang D, Wang W, Sun X, et al. Screening natural antioxidants in peanut shell using DPPH-HPLC-DAD-TOF/MS methods. Food Chem 2012;135(4):2366-71

3. Zhang G, Hu M, He L, Fu P, Wang L, Zhou J. Optimization of microwave-assisted enzymatic extraction of polyphenols from waste peanut shells and evaluation of its antioxidant and antibacterial activities in vitro. Food Bioproc Process 2013;91(2):158-68.

4. Sheng S, Zhang L, Chen G. Determination of 5,7-dihydroxychromone and luteolin in peanut hulls by capillary electrophoresis with a multiwall carbon nanotube/poly(ethylene terephthalate) composite electrode. Food Chem 2014;145(1):555-61.

5. Haryoto H, Yuliati K, Wahyuningtyas N. Antiinflammatory effect of the ethanol extract from the peanut hulls (Arachis hypogaea 1.) in wistar male rats induced by karagenin. Pharmacon 2010;11(1):7-12.

6. Velu K, Elumalai D, Hemalatha P, Babu M, Janaki A, Kaleena PK. Phytochemical screening and larvicidal activity of peel extracts of Arachis hypogaea against chikungunya and malarial vectors. Int $\mathrm{J}$ Mosq Res 2015;2(1):1-8.

7. Win MM, Abdul-Hamid A, Baharin BS, Anwar F, Sabu MC, Pak-Dek MS. Phenolic compounds and antioxidant activity of peanut's skin, hull, raw kernel and roasted kernel flour. Pak J Bot 2011;43(3):1635-42.

8. Husni A, Putra DR, Lelana IY. The antioxidant activity of Padina sp. at various temperatures and drying times 2014;9(2):165-73.

9. Vuong QV, Sadeqzadeh E, Hirun S, Goldsmith CD, Zammitt N, Bowyer MC, et al. Phenolic compounds, antioxidant and anticancer properties of the Australian maroon bush scaevola spinescens (Goodeniaceae). J Bioanal Biomed 2014;2(s12):1-7.

10. Anggraini FR. The level of knowledge and preventing ways to cervical cancer in the Business Faculty of Widya Mandala Catholic University Surabaya. Thesis. Surabaya, ID: Fakultas Kedokteran Universitas Katolik Widya Mandala; 2014.

11. Gao Y, Zhao J, Zu Y, Fu Y, Liang L, Luo M, et al. Antioxidant properties, superoxide dismutase and glutathione reductase activities in HepG2 cells with a fungal endophyte producing apigenin from pigeon pea [Cajanus cajan (L.) Millsp.]. Food Res Int 2012;49(1):147-52.

12. Beara IN, Lesjak MM, Simin DDC, Orcic DZ, Jankovic T, Anackov GT, et al. Comparative analysis of phenolic profile, antioxidant, antiinflammatory and cytotoxic activity of two closely-related Plantain species: Plantago altissima L. and Plantago lanceolata L. Food Res Int 2012;47(1):64-70.

13. Harborne JB. Phytochemical methods, a guide to modern techniques of plant analysis. Bandung, ID: ITB; 1987.

14. Fidrianny I, Puspitasari N, Singgih WM. Antioxidant activities, total flavonoid, phenolic, carotenoid of various shells extracts from four species of legumes. Asian J Pharm Clin Res 2014;7(4):42-6.

15. Kang $\mathrm{OH}$, Choi JG, Lee JH, Kwon DY. Luteolin isolated from the flowers of Lonicera japonica suppresses inflammatory mediator release by blocking NF-kappaB and MAPKs activation pathways in 
HMC-1 cells. Molecules 2010;15(1):385-98.

16. Ghasemzadeh A, Jaafar HZ. Optimization of reflux conditions for total flavonoid and total phenolic extraction and enhanced antioxidant capacity in Pandan (Pandanus amaryllifolius Roxb.) using response surface methodology. ScientificWorldJournal 2014;2014:523120.

17. Irianti T, Puspitasari A, Machwiyyah L, Rabbani H. The activity of radical scavenging of 2,2-diphenyl-1-pycrilhydrazil (DPPH) by ethanolic extracts of mengkudu leaves (Morinda citrifolia L.), brotowali stem (Tinospora crispa L.), its water fraction and its hydrolized fraction. Tradit Med J 2015;20(3):140-8.

18. Markham KR. Techniques of Flavonoid Identification. Bandung, ID: ITB; 1988

19. Boué SM, Carter-Wientjes CH, Shih BY, Cleveland TE. Identification of flavone aglycones and glycosides in soybean pods by liquid chromatography-tandem mass spectrometry. J Chromatogr A 2003;991(1):61-8.

20. Hatam SF, Suryanto E, Abidjulu J. The antioxidant activity of pineapple skin (Ananas comosus (L) Merr) extract 2013;2(1):7-12.

21. Hussain AI, Chatha SA, Noor S, Arshad MU, Khan ZA, Rathore HA, et al. Effect of extraction techniques and solvent systems on the extraction of antioxidant components from peanut (Arachis hypogaea L.) hulls. Food Anal Method 2011;5(4):1-8.

22. Susanti H, Alfian R. Determination of total phenolic content of methanolic extracts red rosell (Hibiscus sabdariffa Linn) calyxs in variation of growing area by spectrophotometry. J Ilmiah Kefarmasian 2012;2(1):73-80.

23. Rohaeti E, Heryanto R, Rafi M, Wahyuningrum A, Darusman L. Prediction of total flavonoids content from Sonchus arvensis L. using a combination of infrared spectroscopy with partial least squares regression. J Kimia 2011;5(2):101-8.

24. Hernani H, Marwati T, Winarti C. Solvent selection on the purification of galangal extracts with extraction. J Pascapanen 2007;4(1):1-8.
25. Wen L, Wu D, Jiang Y, Prasad KN, Lin S, Jiang G, et al. Identification of flavonoids in litchi (Litchi chinensis Sonn.) leaf and evaluation of anticancer activities. J Funct Foods 2014;6(1):555-63.

26. Zhou K, Wang H, Mei W, Li X, Luo Y, Dai H. Antioxidant activity of papaya seed extracts. Molecules 2011;16(8):6179-92.

27. Aksoy L, Kolay E, Agilönü Y, Aslan Z, Kargioglu M. Free radical scavenging activity, total phenolic content, total antioxidant status, and total oxidant status of endemic Thermopsis turcica. Saudi J Biol Sci 2013;20(3):235-9.

28. Venkatesh P, Prakash G, Pavadai P. Design, synthesis and cytotoxic activity of some novel flavones. Int J Pharm Sci Res 2012;3(2):523-7.

29. Nurani LH. Cytotoxicity and antiproliferation assays of Nigella sativa seeds toward Vero and breast cancer (t47d) cells, L. J Ilmiah Kefarmasian 2012;2(1):17-29.

30. Pushpa H, Anand M, Pannangi K, Pradeep P. Ganoderma applanatum (Persoon) Patouillard: As a source of anticancer and antioxidant agent. Int J Pharm Bio Sci 2014;5(2):276-82.

31. Sadeghi-Aliabadi H, Minaiyan M, Dabestan A. Cytotoxic evaluation of doxorubicin in combination with simvastatin against human cancer cells. Res Pharm Sci 2010;5(2):127-33.

32. Ibrahim T, El-Hela A, Elhady N, Abo-Elfetoh N. Phytochemical composition, in vitro antioxidant and cytotoxic activities of seeds of Convolvulus arvensis Linn. Int J Pharm Bio Sci 2016;7(2):107-16.

33. Sak K. Cytotoxicity of dietary flavonoids on different human cancer types. Pharmacogn Rev 2014;8:122-46

34. Plochmann K, Korte G, Koutsilieri E, Richling E, Riederer P, Rethwilm A, et al. Structure-activity relationships of flavonoidinduced cytotoxicity on human leukemia cells. Arch Biochem Biophys 2007;460(1):1-9.

35. Zheng PW, Chiang LC, Lin CC. Apigenin induced apoptosis through p53-dependent pathway in human cervical carcinoma cells. Life Sci 2005;76(2):1367-79. 